\title{
Tomato Business Integration Conduct; Is It the Impact of Marketing Structure? (Tomato Marketing Study in Manggarai Regency, East Nusa Tenggara)
}

\author{
${\text { Fabianus Gangkur }{ }^{*} \text {, Ratya Anindita }}^{2}$, Hery Toiba ${ }^{3}$ \\ ${ }^{1}$ Agricultural Socio-Economic Study Program, Faculty of Health and Agricultural Science, Indonesian \\ Catholic University Santu Paulus Ruteng, Indonesia, Jl. Jenderal Ahmad Yani No.10 Ruteng \\ ${ }^{2,3}$ Department of Socio-Economics, Faculty of Agriculture, University of Brawijaya, Malang, Indonesia, \\ Jl. Veteran, Universitas Brawijaya, Indonesia
}

Received: 23 July 2020; Revised: 26 October 2020; Accepted: 3 November 2020

\begin{abstract}
This study aimed to examine the demand for tomato SCP in Manggarai Regency. The participants were 82 farmers, 7 middlemen, and 16 retailers. The characteristics of the farmers were homogeneous in terms of having a limited area of approximately 0.1-0.5 hectares. A simple random sampling method was then used to determine the participants. Slovin's formula was used to determine the farmer participants. The snowball sampling method was used to assess the sample of middlemen. Market structure data was analyzed by market share, and market concentration used CR4 estimates. Whereas, consumer conduct had been descriptively studied in relation to pricing strategies and business integration. Market performance estimation was made by measuring the margin and the farmer's share. The results showed that the structure of the market for tomatoes in Manggarai Regency was oligopolistic and very concentrated. The CR4 values were as follows: middlemen $(69.95 \%)$, retailers $(54.57 \%)$ and farmers (13.05 per cent). Meanwhile, the market structure affected the market conduct in which traders as price determinant and farmers as price takers. In addition, the middlemen established vertical business integration as an attempt to expand their business, dominate the market and increase their income. Oligopoly market structure and market conduct affected the tomato market in Manggarai Regency. The tomato market performance was inefficient as seen from a wide margin but having small farmer's share. The margin values for channels I and II were Rp12.151,00 and Rp11.525,00 respectively. Whereas the farmer's share was 36.46 percent and 39.74 percent respectively. Reflecting to the results, an accessible price information service is extremely needed for farmers to minimize asymmetry information. In addition, farmers need to maximize the role and work of farmers' groups as a joint marketing agency in order to increase their bargaining position.
\end{abstract}

Keywords: business integration; conduct; performance; tomato

\section{How to Cite:}

Gangkur, F., Anindita, R., \& Toiba, H. (2020). Tomato Business Integration Conduct; Is It the Impact of Marketing Structure? ( Tomato Marketing Study in Manggarai Regency, East Nusa Tenggara ). HABITAT, 31(3), 136-143. https://doi.org/10.21776/ub.habitat.2020.031.3.16

\section{Introduction}

SCP is one of the paradigms that was initially used to examine industrial economics. This model explains that there is a relationship between the structure, actions and success of companies in the field. Structure appears to affect market conduct and market conduct can affect market output over time (Lipczynski, Wilson, and

${ }^{*}$ Correspondence Author.

E-mail: ambikgangkur@gmail.com HP: 085253335399
Goddard 2005; Arsyad \& Kusuma, 2014). As a consequence of this relationship, SCP is one of the methods used to evaluate the market. Specifically, the SCP methodology is used to track competition in a single market at the same time as identifying the causes and consequences of a single market inefficiency (Anindita and Baladina 2017).

The use of SCP as an approach to the study of the cause and effect of an ineffective marketing scheme has been widely used by horticultural researchers. These studies include: Phuu (2016) analyzed marketing of cabbage in Botswana; 
Anggraeni and Baladina (2017) analyzed marketing of potatoes in Sumberbrantas Village, Bumiaji District, Batu City; Baladina (2012) analyzed marketing of carrots in Mantung Agribusiness Sub-Terminal (STA); Idris, Chinda, \& Ahmed (2018) analyzed the Onion Market SCP in Yola, Nigeria; Geremewe (2018) studied Potato Marketing in the West Gojjam Region, Ethiopia; Chogou et al. (2019) analyzed the marketing of Banin watermelon. The results of their studies showed that the market structure for imperfect competition or a tightly clustered oligopoly market has affected the market conduct of middlemen in setting prices and controlling market knowledge causing inefficient market performance.

The studies used SCP approach have been conducted, especially in tomato marketing. In Ghana, Haruna, Nkegbe, and Ustarz (2012). Odufa, Fani, \& Bethel (2016) in South Abeokuta, Ogun, Nigeria; Endris, et.al, (2020) in Habru, North Wollo, Ethiopia. The results of the Haruna et al. (2012) and Endris, et al. (2020) studies indicated a fragmented and oligopolistic market structure even though market efficiency is relatively competitive in terms of margins and profits. Meanwhile, the findings of the Odufa, Fani, \& Bethel (2016) study indicated a perfectly competitive market with an efficient market appearance. Those studies appeared to examine the demand for tomatoes only at the retail level.

This paper raises the question of high marketing margins for tomatoes and small farmers in Manggarai Regency over the last 5 years as an indicator of an ineffective tomato marketing system. Inefficient market is a result of the power of market structure and market conduct. Accordingly, based on previous studies and current issues, this paper proceeds to analyze the marketing of the same tomato product using SCP method. However, this paper focuses more on business integration as a consumer conduct that has an effect on market efficiency. This paper, therefore, illustrates what has not been examined in previous studies, namely the relationship between the market structure and the conduct of business integration, which will have an effect on market efficiency.

\section{Research Methodology}

\subsection{Setting and Sample}

This study was conducted in Manggarai Regency, East Nusa Tenggara Province, Indonesia. The study was performed in January-
February 2020. The data used for tomatoes business were from December 2019 to February 2020. Farmer samples were taken using a simple random sampling method based on the characteristics of a homogeneous collection of land, i.e. between $0.1-0$ and 5 hectares. The number of farmers involved was 82 out of 460 tomato farmers. This equation is based on the Slovin formula (Nasution and Syahbudin 2014) $\mathrm{n}=\frac{N}{N \cdot d \cdot d+1}$ that $\mathrm{n}=$ sample size, $\mathrm{N}=$ population size, $d=$ estimation error $(10 \%)$.

Meanwhile, the sample of middlemen was seven (7) people and sixteen (16) retailers. Sampling middlemen used snowball sampling (Sugiyono, 2016).

\subsection{Data Analysis Technique}

The data anlysis used both descriptive qualitative and quantitative. Market conduct used a descriptive-qualitative analysis, while market structure and efficiency were analyzed quantitatively. An overview of the market structure was inseparable from market share, as the degree of market concentration was determined by the number of companies involved and the market share of the companies in a single market. Lipczynski (2005) suggested that the concentration of the market refers to the amount and distribution of the business size. In the sense that the less companies in one sector and the greater the number of these companies for all the companies in the industry is, the higher the degree of concentration in the industry is. Market share is the proportion of one company's sales volume per total sales in one market (Roy et al. 2018) with a statistical equation as follows:

$$
\begin{aligned}
& S i=\sum_{i=1}^{n} \text { ni } / N \times 100 \\
& S i=\text { market share of the } i \text { - company } \\
& n i=\text { sales volume of the } i \text { - company } \\
& N=\text { total volume of sales } \text { in one market }
\end{aligned}
$$

An analysis tool i.e. Concentration Ratio for Biggest Four (CR4) measures the concentration levels of the four largest tomato buyers in one area in order to assess the market structure. The formula for CR4 used in this analysis is:

\section{$\mathrm{CR}^{4}=$ \\ $\frac{\text { Total Market Share of the Four Biggest Traders }}{\text { Total Market Share in All Markets }} X 100 \%$}

This present study demonstrated two aspects of market conduct, namely pricing practice and business integration. The pricing practices were analysed qualitatively. Company 
integration as another conduct was evaluated quantitatively. Meanwhile, the estimation of market success was based on the estimate of the marketing margin. Marketing margin is price difference between price paid by customers and the price earned by suppliers, and the price difference from the group of marketing services in marketing agencies as a result of profitable activities or the added value (Tomek and Kaiser 2014). Measurement of marketing margin was formulated:

$$
M P=P r-P f \text { atau } M P=B+K
$$

that:

$\mathrm{MP}=$ Marketing Margin $(\mathrm{Rp} / \mathrm{Kg})$

$\mathrm{Pr}=$ Price in consumen level $(\mathrm{Rp} / \mathrm{Kg})$

Pf $\quad=$ Price in farmers level $(\mathrm{Rp} / \mathrm{Kg})$

$\mathrm{B} \quad=$ Marketing cost $(\mathrm{Rp})$

$\mathrm{K}=$ Marketing profits (Rp)

Meanwhile, the amount of Margin at each stage of the marketing agency was determined using the following formula:

$$
\mathrm{Mmi}=\mathrm{Pj}-\mathrm{Pb}
$$

that:

$\mathrm{Mmi}=$ marketing margin at the level of $\mathrm{i}$ agency

$\mathrm{Pj} \quad=$ sale price at the institutional level $\mathrm{i}$

$\mathrm{Pb}=$ purchase price at i marketing agency stage

\section{Result and Discussion}

\subsection{Market Structure}

The data showed that there were farmerproducers and two (2) tomato marketing agencies in Manggarai district, namely wholesalers and retailers. The results of CR4 for farmers and tomato marketing agencies are depicted in the table 1:

Table 1 CR4 Value on Tomato Farmers and Marketing Agencies of the Manggarai Regency

\begin{tabular}{llll}
\hline No & $\begin{array}{l}\text { Farmers and } \\
\text { Marketing } \\
\text { Agency }\end{array}$ & $\begin{array}{l}\text { CR4 } \\
(\boldsymbol{\%})\end{array}$ & $\begin{array}{l}\text { Market } \\
\text { structure }\end{array}$ \\
\hline 1 & Farmer & 13,05 & $\begin{array}{l}\text { Perfect } \\
\text { competition }\end{array}$ \\
2 & Middlemen & 69,95 & Oligopoly \\
3 & Retailers & 54,57 & Oligopoly \\
\hline
\end{tabular}

Based on the data in Table 1, the farmerlevel value was 13.05 per cent. It implies that the market structure of tomatoes at the farmer level was a perfect competition or monopoly market.
What distinguishes between perfectly competitive and monopolistic rivalry was the differentiation of goods. If a differentiation among goods exists, the market created is a monopoly competition market, and a perfect competition market is created in inexistence goods differentiation (Anindita and Baladina 2017). Since there is no differentiation of tomato products in Manggarai Regency, the value of CR4 at the farmer's level indicates a perfectly competitive market.

Meanwhile, at the level of the middlemen, the CR4 value, as shown in the table 1, was 69.95 per cent. It reflects that four tomato wholesalers in Manggarai Regency control about 69.95 per cent of the market share of tomatoes at the middlemen level. At the retailer level as well, the value of CR4 was $54.57 \%$. It means that four retailers managed $54.57 \%$ of the market share of tomatoes at retailer level. Based on the predetermined criteria, if the CR4 value is $<40 \%-<80 \%$, the market structure of tomatoes at wholesaler and retailer level is an imperfect market, i.e. the oligopoly or oligopsony market. The oligopoly market structure can also be found in the Baladina (2012) study; Anggraeni and Baladina (2017) and Endris, et.al (2020) studies.

The high concentration of the tomato market in Manggarai Regency was also shown by the CR4 value of 69.95 per cent at the middlemen level and 54.57 per cent at the retailer level. If the market is concentrated, the level of competition on the market will be lower and there will be potential for middlemen to show unfair conduct on the market, such as collaboration or collusion, in particular when setting up the prices. In similar vein, Church and Ware (2000) and Lipczynski (2005) posit that the less companies in one industry and the greater the market share are, the higher the concentration level and the lower the level of competition are, therefore it tends to dominate price policy. They will boost their own profits.

\subsection{Market conduct}

\subsubsection{Determining Price}

The process of determining the tomato price in Manggarai Regency followed the market mechanism i.e. supply and demand. The fluctuation in supply and demand was directly proportional to the fluctuation in the market price of tomatoes. It means that during a famine season such as the rainy season in December-February, the level of production and availability of tomatoes is limited or decreased, while market 
demand is constant, the price of tomatoes then tends to increase.

Consequently, determining the price of tomatoes on the market was still through negotiations or bargaining between the sellers and the buyers. No matter how far the price-bargaining went through, the superiority of the oligopoly market structure of middlemen over the perfect competition market structure of farmers was very influential. Middlemen in the distribution channel were more informed about the state of supply and demand of tomatoes on the market than producers. The sellers have a real knowledge of the day-today condition of the market, since they spend days on the market.

On the other hand, farmers have little awareness of the market demand and the availability of tomatoes. Farmers also have limited information of prices on the market, as a single center for information on agricultural commodity prices, particularly horticultural commodities, does not exist.

For farmers, sources of knowledge on demand and supply conditions, as well as market prices for tomatoes, is derived from various sources e.g. from traders in markets and farmers who have sold goods. Around 69.5 per cent of Manggarai tomato farmers received market information prior to selling their goods. Price information on the market was garnered from middlemen subscribed to the market or developed trade cooperation.

Meanwhile, the majority of the farmers (30.5 per cent) did not obtain price information on the market. These second category of farmers sold their goods directly on the market with all the consequences such as receiving whatever the price of tomatoes determined on the market. Farmers tended to take the consequences and make few money instead of the tomatoes rotting in the garden and making no money.

Under the conditions mentioned above, how powerful the bargaining between farmersellers and traders in the marketing channel, it is the traders deciding the price of tomato or price makers. Traders in an oligopolistic market system have a higher bargaining power than farmers who are in a perfectly open market structure. Traders monitor the market. They know both the demand for and the availability of tomatoes and prices. Traders are also aware of the possibility of damage and loss if tomatoes are not sold.

The results showed that although bargaining was conducted, $75 \%$ of the middlemen marketing agencies said that traders were the most dominant agency determining the price of tomatoes in Manggarai Regency market. Traders are behaving more as market makers and farmers as price takers.

\subsubsection{Business Integration}

Apart from price determination, the powerful effect of the traders in the oligopolistic market system can be observed from the conduct of business integration, particularly the vertical integration of middlemen. Business integration is an expansion of middlemen' businesses in order to dominate the market and to increase their profit.

The data showed that three tomato marketing agencies in Manggarai Regency have established horizontal and vertical business integration. a. Horizontal integration / business

The three tomato marketing agencies in Manggarai Regency did not only sold the tomato, but also other vegetable commodities, in a similar business line, namely horticulture. The data ehibiteds that all tomato marketing agencies in Manggarai district conducted horizontal business integration or business diversification.

Besides growing tomatoes as a superior crop, tomato farmers and so did traders on marketing channel, i.e. middlemen and retailers often cultivate other vegetable commodities e.g. chilies, beans, cauliflowers, napa cabbage, celery, etc. Besides tomato, other horticultural vegetable goods were often sold in an attempt to raise profits or to anticipate the risk of losses of certain products.

The horizontal business integration of the three marketing agencies is triggered by the characteristics of tomatoes as a horticultural commodity having multicultural property, namely a crop pattern in which many types of plants are planted on the same soil during the seasons (Kemendikbud 2020). Like other horticultural commodities, tomatoes are unable to grow continuously at the same location as an attempt to cut the disease chain in the tomato product. In addition, the prices of tomatoes and horticultural commodities typically fluctuate.

Horizontal business integration or business diversification is one of the alternative solutions to reduce the risk of business failure in a single product. It implies that if the price of the tomato product is at risk of waning, the tomato agribusiness players are able to gain a profit from other horticultural commodities. 
b. Vertical integration

Vertical integration is one of the direct consequences of the dominance of the oligopolistic market system of middlemen over the perfectly competitive market structure of farmers. The data showed that among the three tomato marketing agencies in Manggarai Regency, middlemen were the only marketing agencies establishing vertical business integration. It is not surprising because they have a good market influence on farmers and retailers. Their presence is very influential because most retailers purchase tomato goods from them, so the price of these middlemen has a significant effect on the market.

The middlemen integrated backward and forward vertical business in the marketing process of tomato. The data can be found in Table 2 .

Table 2. Vertical Business Integration of Tomato Middlemen in Manggarai Regency

\begin{tabular}{lcc}
\hline $\begin{array}{l}\text { Name of } \\
\text { Middlemen }\end{array}$ & $\begin{array}{l}\text { Backwards } \\
\text { Vertical } \\
\text { Integration }\end{array}$ & $\begin{array}{l}\text { Forwards } \\
\text { Vertical } \\
\text { Integration }\end{array}$ \\
\cline { 2 - 3 } Farmer & $\mathrm{X}$ & $\mathrm{V}$ \\
DP & $\mathrm{X}$ & $\mathrm{V}$ \\
$\mathrm{NJ}$ & $\mathrm{V}$ & $\mathrm{V}$ \\
$\mathrm{S}$ & $\mathrm{V}$ & $\mathrm{V}$ \\
DJ & $\mathrm{V}$ & $\mathrm{V}$ \\
VA & $\mathrm{X}$ & $\mathrm{X}$ \\
MM & $\mathrm{X}$ & $\mathrm{X}$ \\
KK & 3 & \\
\hline Total & & 5 \\
(person) & 3 & \\
\hline Percentage & & \\
$(\%)$ & $43 \%$ & $71,4 \%$ \\
\hline
\end{tabular}

Ket: $\mathrm{V}=$ Doing activities

$\mathrm{X}=$ Not doing activities

Table 2 showed that the percentage of tomato middlemen in Manggarai Regency conducting backward vertical integration was 43 per cent. They developed or expanded their business by opening up tomato and other horticultural areas. In addition, they also play the role of producer farmers in the input marketing channel.

Furthermore, middlemen also conducted forward vertical integration. They also play a role as retailers in the market to extend their business access. Table 2 depicted that 71.4 per cent of the tomato middlemen in Manggarai Regency were also retailers in the market. They lowered the price of tomatoes in order to dominate the market. It looked like the middlemen took a low profit, but the profit they earned is a little bit higher because of the huge amount of sales.

From the elaboration of horizontal and vertical integration above, it can be seen how powerful the dominance of the oligopoly market of the tomato sellers in Manggarai Regency is. Conducting backward vertical integration in which acting as an input provider on one hand, middlemen were able to suppress the buying-price of tomato products from farmers. On the other hand, they widen up consumer access as retailers conducting vertical business integration. Therefore, they determined the selling-price aiming to gain their profit and dominance.

\subsection{Market Performance}

As mentioned above, the dominance of the oligopoly market system of tomato traders against the perfect competitive farmers has exhibited the sellers as price determinants and farmers as price takers. To expand business and gain more benefit, middlemen conducted vertical business integration so that they still have a bargaining position as the price determinant.

The aforementioned market conduct has definitely affected the performance of the tomato market in Manggarai Regency. The indicators of market performance measured in the present study was the marketing margin and the farmer shares. Therefore, it is essential to investigate the marketing channels for tomatoes in the present study setting.

The tomato marketing system in Manggarai Regency followed two channels, as shown in the figure below.

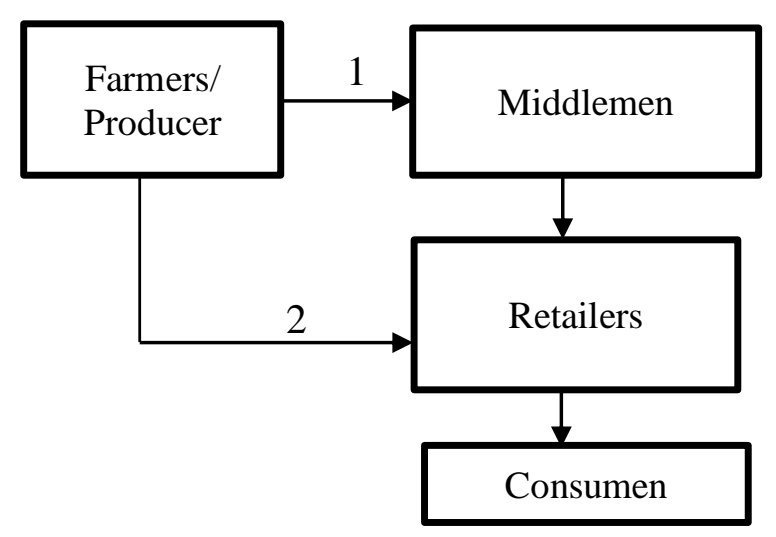

Figure 1. Tomato Marketing Channels in the Manggarai Region

The amount of margin and farmer's share in each marketing channel can be seen in table 3 and table 4 below. 
Table 3. Margin and Farmer Share, Channel I

\begin{tabular}{llll}
\hline $\begin{array}{l}\text { Marketing } \\
\text { Institution }\end{array}$ & \multicolumn{3}{c}{ Channel I } \\
\hline & $\begin{array}{l}\text { Price } \\
\text { (Rp/Kg) }\end{array}$ & Margin & $\begin{array}{l}\text { Price } \\
\text { Share } \\
(\%)\end{array}$ \\
\hline FARMERS & & & 36,46 \\
\hline Production \& & 2.744 & & \\
Marketing Cost & & & \\
Selling-price & 6.974 & & \\
Profit & 4.230 & & 36,74 \\
\hline MIDDLEMEN & & 7.026 & \\
\hline Buying-price & 6.974 & & \\
Marketing cost & 448 & & \\
Selling-price & 14.000 & & \\
Profit & 6.578 & & \\
\hline RETAILERS & & 5.125 & 26,8 \\
\hline Buying-price & 14.000 & & \\
Marketing cost & 196 & & \\
Selling-price & 19.125 & & \\
Profit & 4.929 & 12.151 & 100 \\
\hline
\end{tabular}

Tabel 4. Margin and Farmer Share, Channel II

\begin{tabular}{llll}
\hline $\begin{array}{l}\text { Marketing } \\
\text { Institution }\end{array}$ & $\begin{array}{l}\text { Channel II } \\
\text { Price } \\
(\mathbf{R p} / \mathbf{K g})\end{array}$ & Margin & $\begin{array}{l}\text { Price } \\
\text { Share } \\
(\%)\end{array}$ \\
\hline FARMERS & & & 39,74 \\
\hline $\begin{array}{l}\text { Production \& } \\
\text { Marketing Cost } \\
\text { Selling-price }\end{array}$ & 3.793 & & \\
Profit & 7.600 & & \\
\hline RETAILERS & 3.807 & & \\
\hline Buying-price & 7.600 & 11.525 & 60,26 \\
Marketing cost & 196 & & \\
Selling-price & 19.125 & & \\
Profit & 11.329 & 11.525 & 100 \\
\hline
\end{tabular}

\section{a. Marketing Margin}

Based on Tables 3 and table 4, it can be seen that three marketing agencies were involved in the first channel, while only two agencies were involved in the second channel. The margin for the two marketing channels varied. The margin on the first channel was IDR 12,151.00 and on the second channel was IDR 11,525.00. The highest margin was the longest channel i.e. the first marketing channel. Furthermore, the marketing margin between farmers and middlemen was IDR 7,026.00. The margin between middlemen and retailers was $\operatorname{Rp5}, 125.00$
From the two types of marketing channels mentioned, the margin gap value between the first and the second channels was Rp. 626.00. The highest margin was the longest channel i.e. the first marketing channel. The findings of this study were in congruence with the theory, namely the high or low of the margin is highly affected by the length of the marketing channel and/or the amount or number of marketing agencies involved. The more marketing agencies involved in the sale of goods to customers, the longer the marketing channel is. The longer the marketing channel is, the higher the marketing margin is. Conversely, the fewer marketing agencies involved in the sale of goods to customers, the shorter the marketing channel and the lower the margins are. The results of this research are in line with the Anggraeni \& Baladina (2017) study.

However, the margin gaps of two marketing channels were not wide. The price on the second marketing channel was not much different from the selling-price on the first channel, yet the costs incurred by the farmers were higher on the first channel. It was caused by farmers selling directly on the market did not have social capital with traders to access market information. As a result, retailers in the oligopoly market, as price determinants, had a bargaining position to make bigger profits, namely Rp. 11,525.00. They did not change tomato shape to provide an added value and, thus, raise marketing costs. Another cause was a high volatility of tomotato price because of its easily damaged or rotten. Briz and Felipe (1997), quoted by Anindita \& Baladina (2017), support that wide marketing margins for fruit and vegetables are due to highly price fluctuations.

\section{b. Farmer's Share}

The farmer 's share is defined as the ratio between the price charged or paid by the customer and the price earned by the farmer. This farmer's share illustrates the amount of share earned by farmers obtained from the price paid by the end customer. Based on table 3 and 4, the farmer's share on the first channel was 36.46 per cent and on the second channel was 39.74 per cent. Both farmer's share indicated that the share of the second channel was bigger than the first marketing channel. It was caused by the second channel was the shortest marketing channel. Thus, in line with the theory and findings of previous studies, the shorter the marketing channel is, the greater the share earned by farmers is (Anggraeni and Baladina 2017). Yet, the farmer's share in the first and second channels has not crossed $40 \%$, thus, 
based on the parameters of Downey \& Erickson (1992), the marketing of tomatoes in Manggarai Regency was inefficient.

The comparison of profit-sharing with middlemen and retailers revealed a varied results and spread out. This disparity in profit-sharing is inseparable from the effect of market structure and oligopoly conduct, and the implementation of the marketing function. In the first channel, the share earned by the middlemen was $36.74 \%$. The profitsharing of the middlemen was higher than that of farmers and retailers, namely $26.80 \%$. This is due to the fact that one out of three marketing agencies i.e. the middlemen, has a market power, have a strong impact on price determination and are also supported by the practice of vertical business integration. Thus, the oligopoly market structure has affected the middlemen' conduct to set up the prices and establish vertical business integration resulting in an inefficient market performance for tomatoes.

\section{Conclusions}

a. The structure of the tomato market in Manggarai Regency is oligopolistic and very concentrated among traders, so that the market structure is dominated by perfect competition among farmers.

b. The oligopoly market structure forms the middlemen conduct in such a way that traders practiced forward and backward vertical business integration as a strategy to control and dominate the market and increase profits. The type of backward vertical business integration is to open the field of tomatoes to dominate input channels. While the form of forward vertical business integration is as a retailer. Thus, traders act as a price determinant, while farmers as price taker.

c. As a result, the performance of the tomato market is inefficient, which is expressed in the margins and the farmer's share. Traders get a greater profit-sharing than farmer.

\section{Suggestions}

a. Local governments are required to have price information centers that are readily accesible for farmers in order to minimize information asymmetry.

b. Local governments, along with farmers, need to optimize the positions and functions of farmers' groups as joint marketing agencies in order to improve the status of farmers. c. This research has not taken into account the factors that affect the decision of farmers not to sell tomatoes in a group. Further research should analyze this.

\section{References}

Anggraeni, Melisa Dinda, and Nur Baladina. 2017. "Analisis Struktur, Perilaku Dan Penampilan Pasar Kentang Di Desa Sumberbrantas, Kec. BumiAji, Kota Batu." Jurnal Ekonomi Pertanian Dan Agribisnis $\mathrm{I}(2)$.

Anindita, Ratya, and Nur Baladina. 2017. Pemasaran Produk Pertanian. 1st ed. Yogyakarta: ANDI.

Arsyad, Lincolin, and Stephanus Eri Kusuma. 2014. Ekonomika Industri: Pendekatan Struktur, Perilaku Dan Kinerja. Yogyakarta: UPP STIM YKPN.

Baladina, Nur. 2012. "Analisis Struktur, Perilaku, Dan Penampilan Pasar Wortel Di Sub Terminal Agribisnis(STA) Mantung (Kasus Pada Sentra Produksi Wortel Di Desa Tawangsari, Kecamatan Pujon, Kabupaten Malang)." AGRISE XII(2):1412-25.

Chogou, Sylvain Kpenavoun, Roxène Assogba, Hervé Degbey, Enock Abokini, Enoch G., and Achigan-Dako. 2019. "Market Structure and Performance of Watermelon (Citrullus Lanatus) in Benin." Scientific African 3:1-9.

Church, Jeffrey R., and Roger Ware. 2000. Industrial Organization: A Strategic Approach. United States of America.: The McGraw-Hill Companies.

Downey, W. David, and Steven P. Erickson. 1992. Manajemen Agribisnis. Jakarta: Erlangga.

Endris, Ebrahim, Jema Haji, and Bosena Tegegne. 2020. "Analysis of Vegetables Marketing Performance in Case of Habru District, North Wollo Zone, Ethiopia." Journal of Marketing and Consumer Research 66(March):1-9.

Geremewe, Yaregal Tilahun. 2018. "Structure, Conduct and Performance of Potato Marketing in Sekela District West Gojjam Zone, Amhara Region, Ethiopia." International Journal of Research Studies in Agricultural Sciences (IJRSAS) 4(12):19. 
Haruna, Issahaku, Paul Kwame Nkegbe, and Yazidu Ustarz. 2012. "Structure, Conduct and Performance of Tomato Marketing in Ghana." Journal of Economics and Sustainable Development 3(10):156-63.

Idris, Abdulazeez, Maurice David Chinda, and Muhammad Auwal Ahmed. 2018. "Analysis of Onion Marketing Structure in Yola North Local Government Area of Adamawa State , Nigeria." Internarional Journal of Scientific Research and Managemen (IJSRM) 06(10).

Kemendikbud. 2020. "Kamus Besar Bahasa Indonesia Daring." Retrieved June 7, 2020 (https://kbbi.kemdikbud.go.id/).

Lipczynski, John, John Wilson, and John Goddard. 2005. Industrial Organization: Competition, Strategy, Policy. 2nd ed. Harlow: Pearson Education Limited.

Nasution, Erwin, and Syahbudin. 2014. "Analisis Pemasaran Kopi Di Kabupaten Humbang Hasundutan Provinsi Sumatera Utara." Agrica (Jurnal Agribisnis Sumatera Utara) 7 No 1:40-50.

Odufa, Egbeadumah Maryanne, Djomo Raoul Fani, and Ewung Bethel. 2016. "Structure, Conduct and Performance of Tomato Retailers in Abeokuta South, Ogun State, Nigeria." International Journal of Research Studies in Agricultural Sciences 2(4):3339.

Phuu, Zorinah. 2016. "Analysis of Structure, Conduct and Performance of Cabbage Market in Central District of Botswana." University of Nairobi, Nairobi.

Roy, Nendissa Doppy, Ratya Anindita, Nuhfil Hanani, and Abdul Wahib Muhaimin. 2018. "Dynamics of Degree of Beef Cattle Market Concentration In Kupang of East Nusa Tenggara, Indonesia." RJOAS 6(78)(May):379-84.

Sugiyono. 2016. Statistika Untuk Penelitian. Bandung: Alfabeta.

Sugiyono. 2019. Metode Penelitian Kuantitatif Kualitatif Dan R\&D. Kedua. Bandung: Alfabeta.

Tomek, William G., and Harry M. Kaiser. 2014. Agricultural Product Prices. fifth edit. Ithaca and London: Cornell University Press. 